\title{
Retracing Deep Ecology in the reorientation of Naga identity with special reference to the select works of Easterine Kire Iralu
}

\author{
Subhra Roy \\ Research Scholar, Department of English, Tripura University \\ E-mail: suvizimu@gmail.com
}

\begin{abstract}
The Naga myth of origin underscores the co-existence of and the interconnectivity between the human and the natural world. It is believed that the Nagas once lived in Makhel and a tree stands there as the witness and symbol of Naga origin and unity. The Angami Nagas used to believe that before their dispersal to different parts of the world, three monoliths were erected at Makhrai-Rabu, and these structures represent the Tiger, the Man and the Spirit which stand for the flora and fauna, the human society and the spirit world. With the fall of the first monolith the destruction of the world is initiated and with the fall of the last one the earth witnesses complete doom. It has been reported that only one of these monoliths is standing erect, and it would not be too naive to say that it reminds us of the impending doom that perhaps has already been previewed in the form of natural disasters and other life threatening diseases. In the Naga cultural milieu, nature existed as an independent entity that breathed life into Naga myths, folklores and way of life. In short, it used to define the identity of the primordial Nagas, until their animist world view was replaced by that of Christianity. It was followed by the Indo-Naga conflict, and the Nagas were soon left with confused identities and crises that ran deep into their psyche. Easterine Kire Iralu, the author from Nagaland, tries to reorient the Naga identity by reclaiming the age-old myths and rituals.She tries to retrace the inherent Naga faith in deep ecology that gives equal importance to the distinct parts of the ecosystem that function as a whole.
\end{abstract}

Keywords: co-existence, monoliths, ecosystem, Christianity, identity, deep ecology

Northeastern part of India, nested in the lustrous greeneries and hilly nuances, finds nature within the mode of its very existence. The rich bio-diversity of Northeast India appears often in the literature from the region. It not only breathes life into the literary tropes, but also celebrates the state of interconnectedness between each and every life form in the environment. The sociopolitical anxiety that has been instrumental in defining the Northeast as the conflict zone goes side by side with the ecological crisis that threatens the existence and well-being of life on earth in general. In Son of the Thundercloud, Easterine Kire Iralu, the author from Nagaland, blames the "dark ones" and their greed for the imbalance in the natural world; they are the people who "hoard and guard" and "want the trees and rivers and the stars to bend to their will" (64). She opposes the tendency to exploit the earth as a resource for the comfort and well-being of the human beings who think themselves to be the rightful owners of the earth who occupy a higher strata in the ecological hierarchy. In a way she is espousing the principle of Deep Ecology that resists the othering of different life forms in nature by humans and "has begun to act as a check on man's arrogance and ecological hubris" (Guha 2). Iralu's novels primarily deal with the IndoNaga conflict and the subsequent identity crisis among the Naga people. However, she detests

(C) AesthetixMS 2020. This Open Access article is published under a Creative Commons Attribution Non-Commercial 4.o International License (http://creativecommons.org/licenses/by-nc/4.o/), which permits non-commercial re-use, distribution, and reproduction in any medium, provided the original work is properly cited. For citation use the DOI. For commercial re-use, please contact editor@rupkatha.com. 
being labelled as the writer from the conflict zone as it simply magnifies the process of stereotyping. And that is why her recent novels try to concentrate on the native myths and folklores that have survived on the animist belief system. Retrieving the myths by reconnecting man and nature can reinstate the Naga ethnicity and form a positive autonomous identity that can resist the othering of the Nagas by the mainland India.

The term "Deep Ecology" was coined by the Norwegian philosopher and environmentalist, Arne Dekke Eide Naess, who called for the reorientation of human values that would prefer biocentrism and embrace co-existence of eco-diversities. Naess's philosophy is shaped by a nondualistic approach based on a nonanthropocentric point of view. Acceptance of diversity and interdependence boosts harmony and negates the necessity of binary formation. One of the major principles of Deep Ecology dislodges the existence of man as an entity above nature. The animist world view of the Nagas seems to have internalised this principle long before it got formulated in the western discourse of ecology. It is believed that the Nagas once lived in Makhel and a tree stands there as the witness and symbol of Naga origin and unity,

This tree is known as the oldest tree in the history of the Nagas. It is said that once all the Nagas lived at Makhel.... This tree still stands as a symbol of unity and oneness of the whole Naga tribes. (qtd. in Huber and Blackburn)

The Angami Naga myth of origin professes that before the dispersal of tribesmen to different parts of the world, three monoliths were erected at Makhrai-Rabu, and these structures represent the Tiger, the Man and the Spirit which stand for the flora and fauna, the human society and the spirit world respectively. With the fall of the first monolith the destruction of the world is initiated and with the fall of the last one the earth witnesses complete doom. Tiger, Man and Spirit are believed to be the progeny of the same mother. In Naga Folktales Retold, Kire narrates,

The family of four lived by tilling a field in turns and eating the harvest thereof. Their mother was quite old and the brothers took turns in caring for her.... All three brothers loved their mother dearly... (11).

The 'mother' here is undoubtedly the mother earth, as Temsula Ao mentions it the creation myth of the "Stone-People from Lungterok",

...the progenitors

And forebears

Of the stone-people

Were Born

Out of the womb

Of the earth. (Book of Songs 109)

These myths simply foreground the equal importance of all the entities in the ecological web, and thus call for another significant principle of Deep Ecology, that is, biospherical egalitarianism. It highlights mutual allegiance towards the tenet of 'live and let live' that calls for an equal ground where everything in nature has equal rights. Villie, the protagonist in When the River Sleeps, is a hunter-cum-protector who lives in close proximity with nature and feels at home in the forest. His close partnership with the forest is evident when he declares: "The forest is my wife" (9).

When Villie ventures out of his comfort zone in the forest, where he is assigned the task of protecting the rare genus of tragopans, he has to confront both the benevolent and malevolent forces of nature. His physical and spiritual journey to attain the heart stone of the sleeping river brings him closer to "other-than-human persons", a term coined by A. Irving Hallowell to represent the personhood subscribed to all the entities of nature. According to animists all matters are alive and so they are assigned personhoods- 
"Neo-animism" posits that the world is full of other-than-human "persons", including "salmon person", "tree person", and even "rock persons". The concept of personhood implies relationality and reciprocity, as well as rights. Neo-animists want to see the rights of all "persons" respected". (Halstead)

Thus, the river is alive and so is the stone, and Villie has to wrestle hard with the currents of the river to get hold of its heart stone that has immense magical power. The wrestling between Villie and the 'river person' is a duel between two equals, each trying to overpower the other, but making way for the rightful disposition of willpower. Here Easterine Kire tries to break away from the western individualism and Christianity, and subscribes to the animist beliefs of the primordial Nagas who used to share a symbiotic relation with nature. In the novel Mari, the diary entry of $18^{\text {th }}$ April narrates how the protagonist finds shelter in a cow-shed in the Kikhu woods during the Battle of Kohima which weans the Nagas off their homes and hearths; Mari who is separated from her mother and fiancé is suddenly approached by a bee which "came buzzing and humming and headed directly for me". The Nagas who always noticed "unusual signs in the natural world" used to believe that "if a bee does not leave off bothering a person for a long time, it is because it has a message for the person" (78), and Mari's heart sinks in trepidation, guessing the possible bad news. The premonition turns out to be true; her fiancé has been shot dead by a Japanese sniper. This episode simply reflects the intuitive perception of nature and the interconnection of all life forms. The bee here is not an object existing in the lower rung of the anthropocentric matrix, but like humans it is also a significant part of the whole, that is, the cosmos.

According to Garuba,

An animistic understanding of the world applied to the practices of everyday life has often provided avenues of agency for the dispossessed in colonial and post-colonial Africa. (271)

And this is relevant to the Nagas as well. Such understanding simply poses a challenge to the Western discourse which perceives the world in the mode of subject/object or culture/nature binaries. Animists perceive the other-than-human-persons as cultural beings. Nagaland has been colonized twice, first by the British and then by the Indian forces, and this has led to displacement and imposed silences; the colonial gaze of profit-making initiated the exploitation of nature, and, the colonized natives who were othered and compelled to recede to the periphery became mute spectators. Kire knows very well that only an insider's perspective can break the silences and make the voices registered. Like any other postcolonial writer she explores the tradition of her people to reform an identity, and with this end in view she revives the significance of native cultural symbols and practices like bark-weaving, lycanthropy, soul-twinning and the use of log drum and bitter wormwood. Barkweaving is a dying art in which the bark of the nettle is harvested to make the traditional body cloth of the Nagas. The woman from the village of Barkweavers in When the River Sleeps makes it a point to pass it on to the younger generation. Villie is pleased to see the young women from the Zeliang tribe earn some expertise in cutting the nettle plants "as close to the root as they could" and paring off the skin "so that they would not be stung in the process" (33). The Nagas are shown to be depended on nature for the satisfaction of their basic needs and do not go beyond that to threaten the richness in bio-diversity. This is primarily because they strongly feel the presence of spirits in all the living and non-living objects; for example, the traditional log drum used by the Naga tribes is regarded as a spirit. They talk to it "as though it were a person",

Thank you for agreeing to come and live in our village. We hope you will be happy here. We are very proud that you have chosen to live with us and we rejoice over that. (The LogDrummer Boy 19) 
Assigning an intrinsic value to the log-drum and locating some supernatural power in it present an ethical position that goes beyond the anthropocentric point of view. The mythic ritual of 'tekhumiavi' in which the spirits of men are believed to be transformed into tigers is a closely guarded art among many Naga tribes. It is believed that these were tigers posses immense power and have an access to the spirit world as well. Transforming one's spirit into different animals and reptiles is a common phenomenon among the Nagas. Kire revives such myths and cultural practices in her writings to highlight the close connection between the natural and the supernatural world:

We do not recommend these practices but we are telling you about them because knowledge is always powerful. That is what the age-group houses are for, to impart knowledge of the natural and the supernatural to you so that you go out into the world with knowledge of both, and not disrespectful of either world as some people are. (When the River Sleeps 28)

The connection between the human and non-human entities simply reflects the ethical nature that encourages empathy towards the natural world and beyond. Retrieving the oral culture of indigenous people in postcolonial era often aims to take refuge in nature to find their ecological self.

Postcolonial ecological writings call for the 'Postecolonial theory' which

...advocates ecocentric epistemologies and development models geared to local needs and conditions....and its radical praxis-politics constitutes a definitive "detraditionalisation" involving a shift of authority from "without to within" (i.e., from the centralized, non-local modes of planning to a locally self-empowered one)... (Nayar 73)

This brings Postecolonial theory in close proximity with Deep ecology which prefers local autonomy and decentralization of power. Naess believes that local autonomy makes way for selfsufficiency and self-realization as the sources of need satisfaction are easily available and within hands' reach; the loss of " 'one's roots', 'my surroundings', 'our surroundings'” causes "the loss of an appreciable part of one's self" (Ecology, Community and Lifestyle 62). In Dwellers in the Land: The Bioregional Vision, Sale highlights "people do not, other things being equal, pollute and damage those natural systems on which they depend for life and livelihood" (54). This simply makes identity the bi-product of one's bio-community. During the British colonial intervention, the Naga agrarian culture faced various challenges; the introduction of the monetary economy alienated the Nagas from their own land. The barter system of trading, which brought avenues for learning the language of another tribe, turned obsolete and this harnessed inter-tribe alienation too,

It's a great pity that barter trading has become obsolete. Sad that the younger ones haven't learned other languages. It is always a boon to know another language... (When the River Sleeps 35)

The influx of money from the Government of India after the creation of the state of Nagaland gradually severed them from the agrarian life style. According to Verrier Elwin, the Nagas were

...passionately attached to his land, his system of land-tenure, the arrangements for the government of his village, the organization of cultivation, the administration of tribal justice through the village and tribal courts. (9)

Attachment to the land and its environment was an integral part of Naga identity and Kire tries to revive that through the use of folklores and peoplestories which are based on the oral mode of story-telling. Story-tellers are the healers and weavers; they connect and heal. In fact the traditional stories and myths of indigenous people are designed to connect the biotic elements of nature. 
Absence of stories leads to the absence of myths and absence of myths robs people of the faith and compassion in their hearts. The myths speak of co-existence and when they are disposed off, the doom is inevitable. In Son of the Thundercloud, the drought was man-made; it "came as a result of people rejecting the joyful stories..." (64). The storyteller is no less powerful than the village seer. Both believe in retaining the equilibrium of the natural world,

We give life, not death. We give life to whomsoever and whatsoever desires to come into being. (96)

This all-embracing attitude runs deep in Naga psyche, and Kire believes that invoking this worldview can help the Nagas transcend the stereotypical identities imposed upon them by the colonizers. Easterine Kire who detests the mainlanders' tendency to sniff out tension and conflict in Northeast India and its writings, says:

Let media stop defining the North-east by the conflicts going on there. Let media focus on ordinary people and their lives. Let exoticization of the NE stop! (Longkumer, 2014).

The Naga identity, which has always been the product of outsiders' imagination and indulgence, is now going through a metamorphosis. And retracing the cultural history and the inherent ecological faiths in the Naga worldview is the only way to chisel out the Naga Self that can subvert the othering of the Nagas by the 'mainland' India.

\section{References}

Ao, Temsula. Book of Songs: Collected Poems 1988-2007. Heritage, 2013.

Elwin, Verrier. Nagaland. P. Dutta for the Research Department, Adviser's Secretariat, 1961.

Garuba, Harry. "Explorations in Animist Materialism: Notes on Reading/Writing African Literature, Culture, and Society." Public Culture. Vol. 15, no. 2, April 2003, pp. 261-85, ResearchGate, 10.1215/08992363-15-2-261

Guha, Ramchandra. "Radical American Environmentalism and Wilderness Preservation: A Third World Critique." https://www.coursehero.com/file/46272238/Guha-A-Third-World-Critiquepdf/

Halstead, John. "Branches of the Deep Ecology Tree: Neo-Animism and Bioregionalism: Reuniting human and nature". The Allergic Pagan. 27 September, 2014. https://www.patheos.com/blogs/allergicpagan/2014/o9/27/branches-of-the-deep-ecology-tree-neoanimism-and-bioregionalism/

Huber, Toni and Blackburn, Stuart (ed.). Origins and Migrations in the Extended Eastern Himalayas. BRILL, 2012.

Kire, Easterine. Mari. Zubaan, 2010.

---. Naga Folktales Retold. Barkweaver, 2009.

---. Son of the Thundercloud. Speaking Tiger Publishing Pvt. Ltd, 2016.

---. The Log-Drummer Boy. Barkweaver, 2013.

---. When the River Sleeps, Zubaan, 2014.

Longkumer, I. Watitula. "Reading Terror in Literature: Exploring Insurgency in Nagaland through Temsula Ao's These Hills Called Home: Stories from a War Zone." Sanglap: A Journal of Literary and Cultural 
Inquiry. Vol.1, no.1, 2014, pp. 115-128. Web. http://sanglapjournal.in/index.php/sanglap/article/view/17/12.

Naess, Arne. Ecology, Community and Lifestyle. Cambridge University Press, 1989.

Nayar, Pramod K. "Postecolonial Theory: A New Ontopology and Radical Politics". Journal of Contemporary Thought , 1999, pp.71-83.

Sale, Kirkpatrick. Dwellers in the Land: The Bioregional Vision. Sierra Club Books, 2000.

Subhra Roy is working on the English literature from the Northeastern part of India. She has successfully defended her thesis in the final Viva Voce exam and is awaiting the awarding of the doctoral degree. Her articles have been published in various e-journals like the Muse India, the Language in India, the Criterion and the Langlit. 